5. Сухомлинський В. О. Проблеми виховання всебічно розвиненої особистості. Вибрані твори: в 5 т. Київ: Рад. шк, 1976. Т. 1.654 с.

6. Фромм Е. Мати чи бути? / пер. $з$ англ. Київ: Укр. письм., 2010. 222 с.

7. Bloom B. S. Taxonomy of Educational Objectives The Classification of Educational Goals. Handbook 1: Cognitive Domain. New York: David McKeyCo. 1956.207 p.

\section{REFERENCES}

1. Atanov, H. O. (2008). Znannia yak zasib navchannia: navch. posibnyk [Knowledge as a learning tool: tutorial]. Kyiv: Kondor, 236 p. [in Ukrainian].

2. Bekh, I. D. (2003). Vykhovannia osobystosti. U 2 kn. Kn. 1. Osobystisno oriientovanyi pidkhid: teoretykotekhnolohichni zasady [Parenting. In 2 books. Book 1. Personally oriented approach: theoretical and technological principles]. Kyiv: Lybid, 280 p. [in Ukrainian].

3. Ovcharuk, O. V. (Ed.). (2004). Kompetentnisnyi pidkhid u suchasnii osviti: svitovyi dosvid ta ukrainski perspektyvy [Competency approach in modern education: world experience and Ukrainian perspectives]. Kyiv: K.I.S. Publ., 112 p. (Library for Educational Policy). [in Ukrainian].

4. Rudnytska, O. P. (2005). Pedahohika: zahalna ta mystetska: navchalnyi posibnyk [Pedagogy: general and artistic: a manual]. Ternopil: Educational book - Bohdan, 360 p. [in Ukrainian].

5. Sukhomlynskyi, V. O. (1976). Problemy vykhovannia vsebichno rozvynenoi osobystosti. Vybrani tvory [Problems of education of a fully developed personality. Selected Works] vol. 5, Kyiv: Soviet school. Vol. 1, 654 p. [in Ukrainian].

6. Fromm, E. (2010). Maty chy buty? per. $z$ anhl. [To be or to be? translation from English]. Kyiv: Ukr. pysm, 222 p. [in Ukrainian].

7. Bloom, B. S. (1956). Taxonomy of Educational Objectives: The Classification of Educational Goals. Handbook 1: Cognitive Domain. New York: David McKey Co, 207 p. [in English].

Стаття надійшла до редакції 05.05.2018

УДК 378

DOI:

Інна Шелудько, кандидат педагогічних наук, стариий викладач кафедри професійної освіти та комп 'ютерних технологій

Глухівського національного педагогічного університету імені Олександра Довженка

\title{
ВЕБ-КВЕСТ ЯК ІННОВАЦИЙНИЙ МЕТОД ФОРМУВАННЯ ТВОРЧОЇ ОСОБИСТОСТІ
}

У статті розглядається веб-квест як один з методів формування творчої особистості в сучасних умовах освіти. Охарактеризовано поняття “веб-квест”, проаналізовано види завдань для веб-квестів. Розкрито структуру та систему оцінювання веб-квестів. 3'ясовано, щзо впровадження таких інновачійних методів в навчально-виховний прочес як веб-квест сприяє підвищенню якості навчання, зацікавленості учнів і викладачів, розвитку компетенцій та є важливою стадією процесу реформування традииійної системи освіти в контексті глобалізації.

Ключові слова: веб-квест; інновачійні методи; інформаційно-комунікаційні технологіӥ; творча особистість.

Табл. 1. Літ. 7.

Inna Sheludko, Ph.D.(Pedagogy), Senior Lecturer of the Vocational Education and Computer Technology Department Hlukhiv Oleksandr Dovzhenko National Pedagogical University

\section{WEB-QUESTASANINNOVATIVEMETHODOFFORMATIONOFCREATIVE PERSONALITY}

In the article the web-quest is considered as one of the methods of formation of a creative person in modern conditions of education. The concept "web quest" is described, the types of tasks for web quests are analyzed: transfer, planning and design, self-knowledge, compilation, creative task, analytical task, detective, puzzle, mysterious history, consensus, evaluation, journalistic investigation, beliefs, scientific research.

The structure of web quests, which should consist of the following elements: introduction (wording of the topic, description of the main roles of the participants, the quest script, work plan or oral quest survey), is revealed; the central task (tasks, questions on which participants should find an answer within the framework of an independent study, the final result to be achieved); a list of information resources that can be used during research, including Internet resources; description of the main stages of work; guide to action; conclusion (research results, questions for the further development of the topic).

The system of evaluation of web quests is highlighted and the following criteria are highlighted: experimental and creative work, quality of argumentation, originality of work, skills in microgroup, oral presentation, multimedia presentation, written text, etc. 
The following characterological features of the creative person are singled out: deviation from the template; originality; initiative; persistence; high self-organization; efficiency.

It is stated that the introduction of such innovative methods in the educational process as a web quest contributes to the improvement of the quality of education, the interest of students and teachers, the development of competences and is an important stage in the process of reforming the traditional educational system in the context of globalization.

Keywords: Web-quest; an innovative information and communication technology; creative personality.

П остановка проблеми в загальному вигляді. Впровадження інноваційних засобів в навчально-виховний процес сприяє підвищенню якості навчання, зацікавленості учнів і викладачів, розвитку компетенцій і $\epsilon$ важливою стадією процесу реформування традиційної системи освіти в контексті глобалізації. Однією з таких методик, яка вчить знаходити необхідну інформацію, піддавати іiі аналізу, систематизувати і розв'язувати поставлені задачі $є$ методика веб-квестів [1].

Аналіз основних досліджень та публікацій. Проблему розробки і використання веб-квестів у навчальному процесі активно вивчають зарубіжні та вітчизняні вчені: B. Dodge, T. March, О. Гапеева, Г. Гриневич, Г. Шаматон, В. Шмідт та ін. Існує два погляди вчених на поняття вебквеста: це веб-квест як освітній продукт і вебквест - технологія. Російські дослідники Я. Биховський, А. Хуторський відзначають, що освітні веб-квести - це сторінки освітньої тематики на сайтах в мережі Інтернет, мають гіперпосилання на інші сторінки в мережі заданої тематики [2]. Вони служать додатковим стимулом для індивідуалізації навчання студентів, розширюючи кругозір і збагачуючи додатковими знаннями.

Інші вчені (Н. Кононець, В. Осадчук) розглядають веб-квест як інноваційну особистісно-орієнтовану технологію навчання, основною метою якої $є$ самостійний пошук школярами необхідної для навчання інформації. Основоположники технології веб-квест В. Dodge, T. March визначають веб-квест як дослідницьку довідково-орієнтовану діяльність, в результаті якої студенти здійснюють пошук інформації, використовуючи Інтернет-ресурси і відео конференції [5].

Проблему розробляння та використання вебквестів у навчальному процесі активно вивчають зарубіжні та вітчизняні науковці: Б. Додж, Т. Марч, М. Андрєєва, О. Гапеєва, М. Гриневич, Г. Шаматонова та В. Шмідт.

Мета статті - теоретично обгрунтувати сутність та шляхи впровадження веб-квестів як одного з інноваційних методів розвитку творчої особистості.

Виклад основного матеріалу дослідження. Згідно вільної Інтернет-енциклопедії “Вікіпедія”, квест - один 3 основних жанрів ігор, що вимагають від гравця розв'язання розумових завдань для просування по сюжету. Сюжет може бути визначеним або ж давати безліч результатів, вибір яких залежить від дій гравця [4].

Веб-квест (webquest) в педагогіці - це проблемне завдання 3 елементами рольової гри, для виконання якого використовуються інформаційні ресурси Інтернету.

Веб-квест - це сайт в Інтернеті, 3 яким працюють студенти, виконуючи те або інше навчальне завдання. Розробляються такі вебквести для максимальної інтеграції Інтернету в різні навчальні предмети на різних рівнях навчання в навчальному процесі. Вони можуть охоплювати окрему проблему, тему, можуть бути i міжпредметними. Тематика веб-квестів може бути найрізноманітнішою, проблемні завдання можуть відрізнятися мірою складності. В основі веб-квесту лежить індивідуальна або групова робота студентів (з розподілом ролей) за рішенням заданої проблеми 3 використанням інтернет-ресурсів підготовлених учителем [4].

П. Шаматонова акцентує увагу на тому, що веб-квест - це захоплююча подорож в мережі Інтернет, що передбачає запити в різних пошукових системах, отримання досить великого обсягу інформації, їі аналіз, систематизацію та подальше презентацію [3].

Фактично, веб-квест є дидактичної структурою, в рамках якої викладач формує пошукову діяльність студентів, задає параметри цієї діяльності і визначає іiї тимчасові межі. При цьому вчитель перестає бути “джерелом знань”, створює необхідні умови для пошуку інформації, а школярі перетворюються 3 пасивних об'єктів навчальної діяльності в іiі активних суб'єктів. По суті, веб-квест є інтерактивним процесом, в ході якого студенти виявляють мотиви до самостійного добування необхідних знань.

Основна перевага використання веб-квестів на уроках спеціальних дисциплін викладачів професійного навчання це те, що крім вдосконалення умінь і навичок роботи в мережі Інтернет, пошуку потрібної інформації, студенти вдосконалюють також і навички роботи з певним програмним забезпеченням (MS PowerPoint, MS Publisher, MS Excel тощо). 
Розробляються веб-квести для максимальної інтеграції Інтернету в різні навчальні предмети, на різних рівнях навчання в навчальному процесі. Вони охоплюють окрему проблему, навчальний предмет, тему, можуть бути і міжпредметні.

Розрізняють два типи веб-квестів [6]:

- для короткочасної роботи (мета: поглиблення знань та їх інтеграція, розраховані на одно-три заняття);

- для тривалої роботи (мета: поглиблення i перетворення знань, розраховані на тривалий термін, може бути на семестр або навчальний рік).

Веб-квести найкраще підходять для роботи в міні групах, однак, існують і веб-квести, призначені для роботи окремих учнів. Додаткову мотивацію при виконанні веб-квеста можна створити, запропонувавши учням вибрати ролі (наприклад, учений, журналіст, детектив, архітектор тощо). Веб-квест може стосуватися одного предмета або бути міжпредметним. Дослідники відзначають, що в другому випадку робота буде ефективнішою.

Розробниками веб-квеста, як навчального завдання $є$ Берні Додж та Том Марч, професори освітніх технологій Університету Сан-Дієго (США). Ними визначено такі види завдань для веб-квестів [3]:

- переказ - демонстрація розуміння теми, на основі подання матеріалів 3 різних джерел в новому форматі: створення презентації, плаката, оповідання.

- планування та проектування - розробка плану або проекту, на основі заданих умов.

- самопізнання - будь-які аспекти дослідження особистості.

- компіляція - трансформація формату інформації, отриманої з різних джерел: створення книги кулінарних рецептів, віртуальної виставки, капсули часу, капсули культури.

- творче завдання - творча робота в певному жанрі - створення п'єси, вірші, пісні, відеоролика.

- аналітична задача - пошук і систематизація інформації.

- детектив, головоломка, таємнича історія - висновки на основі суперечливих фактів.

- досягнення консенсусу - винесення рішення з гострої проблеми.

- оцінка - обгрунтування певної точки зору.

- журналістське розслідування - об'єктивний виклад інформації (поділ думок і фактів).

- переконання - схиляння на свій бік опонентів або нейтрально налаштованих осіб.

- наукові дослідження - вивчення різних явищ, відкриттів, фактів на основі унікальних онлайн джерел.
На думку Є.С. Полат, веб-квест повинен мати наступну структуру:

- вступ (формулювання теми, опис головних ролей учасників, сценарій квеста, план роботи або огляд усного квеста);

- иентральне завдання (завдання, питання, на які учасники мають знайти відповідь в межах самостійного дослідження, який підсумковий результат має бути досягнутий);

- список інформаційних ресурсів, які можна використати під час досліджень, у тому числі ресурси Інтернет;

- опис основних етапів роботи; керівництво до дії;

- висновок (підсумки дослідження, питання для подальшого розвитку теми).

Ключовим розділом будь-кого веб-квесту є детальна шкала критеріїв оцінки, спираючись на яку, учасники проекту оцінюють самих себе, товаришів по команді. Цими ж критеріями користується і учитель.

Веб-квест є комплексним завданням, тому оцінка його виконання повинна грунтуватися на декількох критеріях, орієнтованих на тип проблемного завдання i форму подання результату [5].

Б. Додж рекомендує використовувати від 4 до 8 критеріїв, які можуть включати оцінку: дослідної та творчої роботи, якості аргументації, оригінальності роботи, навичок роботи в мікрогрупі, усного виступу, мультимедійної презентації, письмового тексту тощо.

Серед характерологічних особливостей творчої особистості виділяють: відхилення від шаблону; оригінальність; ініціативність; наполегливість; високу самоорганізацію; працездатність. Ці особливості можна реалізувати при проведенні веб-квестів. Завдання квесту повинні бути націлені на розвиток цих характеристик.

Висновки. Таким чином, робота 3 вебквестами підвищує IT-компетентність вчителя та учня, знайомить 3 новими видами сучасних Інтернет-сервісів, розвиває інформаційну культуру, сприяє розвитку критичного мислення, формує вміння знаходження шляхів розв'язку проблеми та завдання в цілому.

Створення та проведення квестів $є$ нескладним процесом, що не потребує завантаження додаткових програм або одержання специфічних технічних знань та навичок - необхідним $є$ лише комп'ютер, $з$ доступом до мережі Інтернет та творче мислення.

Перспективами подальших розвідок у даному напрямку $є$ визначення основних 
Критерії оцінювання учнів за Л. Д. Желізняком

\begin{tabular}{|c|c|c|c|}
\hline & Середній & Достатній & Високий \\
\hline $\begin{array}{l}\text { Розуміння } \\
\text { завданя }\end{array}$ & $\begin{array}{l}\text { Подано матеріали, що не } \\
\text { мають } \\
\text { безпосереднього } \\
\text { відношення до } \\
\text { теми; використовується } \\
\text { одне } \\
\text { джерело, зібрана } \\
\text { інформація не } \\
\text { аналізується і не } \\
\text { оцінюється }\end{array}$ & $\begin{array}{l}\text { Подаються, як матеріали, } \\
\text { що } \\
\text { мають безпосереднє } \\
\text { відношення до теми, так } \\
\text { і матеріали, що не мають } \\
\text { відношення до неї; } \\
\text { використовується } \\
\text { обмежена } \\
\text { кількість джерел }\end{array}$ & $\begin{array}{l}\text { Робота демонструє точне } \\
\text { розуміння } \\
\text { завдання }\end{array}$ \\
\hline $\begin{array}{l}\text { Виконання } \\
\text { завдання }\end{array}$ & $\begin{array}{l}\text { Випадкова підбірка } \\
\text { матеріалів; } \\
\text { інформація неточна або не } \\
\text { має відношення до теми; } \\
\text { неповні } \\
\text { відповіді на питання; не } \\
\text { робляться спроби оцінити } \\
\text { або } \\
\text { проаналізувати } \\
\text { інформацію }\end{array}$ & $\begin{array}{l}\text { Не кожна інформація взята } \\
\text { з достовірних джерел; } \\
\text { частина } \\
\text { інформації неточна або не } \\
\text { має } \\
\text { прямого відношення до } \\
\text { теми }\end{array}$ & $\begin{array}{l}\text { Оцінюються роботи різних } \\
\text { періодів; висновки } \\
\text { аргументовані; } \\
\text { усі матеріали мають } \\
\text { безпосереднє } \\
\text { відношення до теми; } \\
\text { джерела } \\
\text { цитуються правильно; } \\
\text { використовується } \\
\text { інформація } \\
\text { з достовірних джерел }\end{array}$ \\
\hline $\begin{array}{l}\text { Результат } \\
\text { роботи }\end{array}$ & $\begin{array}{l}\text { Матеріал логічно не } \\
\text { побудований } \\
\text { і поданий зовні } \\
\text { непривабливо; не } \\
\text { дається чіткої відповіді на } \\
\text { поставлені завдання }\end{array}$ & $\begin{array}{l}\text { Точність і } \\
\text { структурованість } \\
\text { інформації; привабливе } \\
\text { оформлення роботи. } \\
\text { Недостатньо виражена } \\
\text { власна } \\
\text { позиція і оцінка } \\
\text { інформації. } \\
\text { Робота схожа на інші } \\
\text { учнівські } \\
\text { роботи }\end{array}$ & $\begin{array}{l}\text { Чітке і логічне подання } \\
\text { інформації; } \\
\text { уся інформації має } \\
\text { безпосереднє } \\
\text { відношення до теми, точна, } \\
\text { добре } \\
\text { структурована і } \\
\text { відредагована. } \\
\text { Демонструється критичний } \\
\text { аналіз } \\
\text { і оцінка матеріалу, } \\
\text { визначеність } \\
\text { позиції }\end{array}$ \\
\hline $\begin{array}{l}\text { Творчий } \\
\text { підхід }\end{array}$ & $\begin{array}{l}\text { Учень просто копіює } \\
\text { інформацію } \\
\text { із запропонованих джерел; } \\
\text { немає } \\
\text { критичного погляду на } \\
\text { проблему; } \\
\text { робота мало пов'язана } 3 \\
\text { темою } \\
\text { веб-квеста }\end{array}$ & $\begin{array}{l}\text { Демонструється одна точка } \\
\text { зору на проблему; } \\
\text { проводяться } \\
\text { порівняння, але не } \\
\text { робляться } \\
\text { висновки }\end{array}$ & $\begin{array}{l}\text { Подано різні підходи до } \\
\text { вирішення } \\
\text { проблеми. Робота } \\
\text { відрізняється } \\
\text { яскравою індивідуальністю } \\
\text { і виражає точку зору } \\
\text { мікрогруп }\end{array}$ \\
\hline
\end{tabular}

напрямів впровадження веб-квестів у підготовці майбутніх інженерів-викладачів швейної галузі.

\section{ЛІТЕРАТУРА}

1. Енциклопедія освіти / Акад. пед. наук України, головний ред. В.Г. Кремень. - К.: Юрінком Інтер, 2008. -1040 .

2.Москаль Ю. Світові тенденції розвитку заочної та дистанційної освіти / Ю. Москаль // Психологія і суспільство. - 2008. - №3. - С. 116-122.

3. Осадчук О.Л. Управление самостоятельной работой студентов: метод. пособие / О.Л. Осадчук. Омск: Полиграф. центр КАН, 2009 - 156 с.
4. Педагогіка вищої школи: навч. посіб. / Курлянд 3.Н., Хмелюк Р.І., Семенова А.В. та ін.; за ред. 3.Н. Курлянд. -3-тє вид. -К.: Знання, 2007. -495 с.

5. Селевко Г.К. Современные образовательные технологии / Г.К. Селевко. - М.: Народное образование: учебное пособие, 1998. $-256 \mathrm{c.}$

6. Сысоев П.В. Дидактические свойства и функции современных информационных и коммуникационных технологий / П.В. Сысоев // Иностр. яз. в шк. -2012. №6. - С. 12-21.

\section{REFERENCES}

1. Kremen,V.H. (Ed.). (2008). Entsyklopedija osvity 
[Entsyklopedija of edukation]. Kyiv: Yuricom Inter, 1040 p. [in Ukrainian].

2. Moskal, Yu. (2008). Svitovi tendentsii rozvitku zaochnoi ta distantsiynoi vishchoi osviti [World tendencies of the development correspondence and distance higher education]. Psychology and society, vol. 3, pp. 116-122. [in Ukrainian].

3. Kurliand, Z.N., Kheljuk, R.I. \& Semenova, A.V. et. al.; Kurliand, Z.N., (Ed.). (2007). Pedagogika vyshoji shkoly: navch. Posibnyk [Pedagogy of higher education: teach. guidances]. Kyiv: Znannia, 495 p. [in Ukrainian].

4. Selevko, G.K. (1998). Sovremennye obrazovatelnye tekhnologi [Modern educational technologies]. Moskov: Narodnoe obrasovanie:uchebnoe posobie, 256 p. [in Russian]. 5. Sysoev, P.V. (2012). Didakticheskie svoystva i funktsii sovremennykh informatsionnykh i kommunikatsionnykh tekhnologiy [Didactical features and functions of modern informational and communicational technologies]. Foreign languages at shool, vol. 6 . Moscow, pp. 12-21. [in Russian].

6. Osadchuk, O.L. (2009). Upravlenie samostoyatelnoy rabotoy studentov: metod. posobie [Management of the self-studying work of students: methodological guide]. Omsk: Publishing center KAN, 156 p. [in Russian].

Стаття надійшла до редакції 25.04.2018

УДК 378.011.3-051:373.2(73)

DOI:

Юрій Калічак, кандидат педагогічних наук, доиент кафедри загальної педагогіки та дошкільної освіти Дрогобииького державного педагогічного університету імені Івана Франка

\section{ФОРМУВАННЯ КОМПЕТЕНТНОСТІ ВИХОВАТЕЛЯ ЗАКЛАДІВ ДОШКІЛЬНОЇ ОСВІТИ В ПРОЦЕСІ ПРОФЕСІЙНОЇ ПІДГОТОВКИ}

У статті розглянуто проблему формування професійної компетентності фахівців дошкільної освіти; проаналізовано підходи до організації професійної підготовки педагогів; визначено складові частини професійної компетентності; обтрунтовано умови творчої самореалізації педагогів у галузі дошкільноі освіти з урахуванням новітніх підходів до виховання дітей дошкільного віку.

3'ясовано формування професійної компетентності педагогів передбачає не лише засвоєння дисциплін професійного ичклу, але $і$ знання сучасних концепцій дошкільної освіти, а саме компетентнісного, особистісноорієнтованого та діяльнісного підходів до організації освітнього процесу в закладах дошкільної освіти.

Ключові слова: формування професійної компетентності; умови творчої самореалізачії; професійна освіта; дошкільна освіта; вихователь дітей дошкільного віку.

Jim. 10.

Yuriy Kalichak, Ph. D.(Pedagogy), Associate Professor of the General Pedagogy and Preschool Education Department Drohobych Ivan Franko State Pedagogical University

\section{THE FORMATION OF COMPETENCE OF EDUCATOR OF INSTITUTIONS OF PRESCHOOL EDUCATION IN THE PROCESS OF PROFESSIONAL TRAINING}

The article analyzes the peculiarities of vocational training of preschool education specialists, the main priority of which is the combination of personal and activity approaches. A modern institution of higher pedagogical education should train a student who will work with children of preschool age, actively participate in social life, create conditions for the development of a person who can not only assess the situation and adapt to social changes, but also think in an original and non-standard way and generate and implement ideas, develop ways of positive transformation, initiative and autonomy, and creativity.

The etymology and meaning of the term "competence" have been clarified, which gives grounds to return in the interpretation of this definition to the European understanding of the most basic two meanings of the word: the legal and psychological ones, since nowadays there is no simple unambiguous interpretation on this issue.

It was found out that the professional competence of the pre-school educator involves a combination of professional and personal qualities necessary for successful pedagogical activity. A professionally competent teacher is the one who carries out the pedagogical activity and pedagogical communication at high level, and achieves continuously high results in teaching and upbringing of preschoolers.

The process of development of professional competence is characterized as a bloom of creative individuality, formation of susceptibility to pedagogical innovations, ability to adapt to changes in the pedagogical environment.

It has been proved that the formation of the professional competence of the future teacher of pre-school establishments occurs during the study at an institution of higher pedagogical education. It is important to choose such an institution, which would train the teachers with the necessary luggage of competencies. 